\title{
Impact of foreign direct investment, remittances and official development assistance on economic growth: panel data approach
}

\author{
Amna Zardoub \\ Faculty of Economics and Management of Sousse, University of Sousse, \\ Sousse, Tunisia, and \\ Faouzi Sboui \\ Faculty of Economics and Management of Mahdia, University of Monastir, \\ Monastir, Tunisia
}

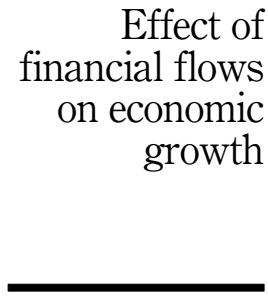

Received 9 April 2020 Revised 13 November 2020 Accepted 14 November 2020

\begin{abstract}
Purpose - Globalization occupies a central research activity and remains an increasingly controversial phenomenon in economics. This phenomenon corresponds to a subject that can be criticized through its impact on national economies. On the other hand, the world economy is evolving in a liberalized environment in which foreign direct investment plays a fundamental role in the economic development of each country. The advent of financial flows - FDI, remittances and official development assistance - can be a key factor in the development of the economy. The subject of this article is to analyses the effect of financial flows on economic growth in developing countries. Empirically, different approaches have been employed. As part of this work, an attempt was made to use a panel data approach. The results indicate ambiguous effects and confirm the results of previous work.

Design/methodology/approach - The authors seek to study the effect of foreign direct investment, remittances and official development assistance (ODA) and some control variables i.e. domestic credit, life expectancy, gross fixed capital formation (GFCF), inflation and three institutional factors on economic growth in developing countries by adopting the panel data methodology. Then, the authors will discuss empirical tests to assess the econometric relevance of the model specification before presenting the analysis of the results and their interpretations that lead to economic policy implications. As part of this work, the authors have rolled panel data for developing countries at an annual frequency during the period from 1990 to 2016. In a first stage of empirical analysis, the authors will carry out a technical study of the heterogeneity test of the individual fixed effects of the countries. This kind of analysis makes it possible to identify the problems retained in the specific choice of econometric modeling to be undertaken in the specificities of the panel data.

Findings - The empirical results validate the hypotheses put forward and indicate the evidence of an ambiguous effect of financial flows on economic growth. The empirical findings from this analysis suggest the use of economic-type solutions to resolve some of the shortcomings encountered in terms of unexpected effects. Governments in these countries should improve the business environment by establishing a framework that further encourages domestic and foreign investment.
\end{abstract}

\section{JEL Classification - F22, Q56}

(C) Amna Zardoub and Faouzi Sboui. Published in PSU Research Review. Published by Emerald Publishing Limited. This article is published under the Creative Commons Attribution (CC BY 4.0) licence. Anyone may reproduce, distribute, translate and create derivative works of this article (for both commercial and non-commercial purposes), subject to full attribution to the original publication and authors. The full terms of this licence may be seen at http://creativecommons.org/licences/by/4.0/legalcode

The authors are grateful to an anonymous referees and the editor for many helpful comments and suggestions.

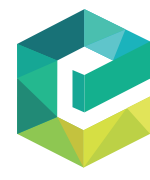

PSU Research Review Emerald Publishing Limited DOI 10.1108/PRR-04-2020-0012 
Originality/value - In this article, the authors adopt the panel data to study the links between financial flows and economic growth. The authors considered four groups of countries by income.

Keywords Economic growth, Foreign direct investment, Remittances, Official development assistances, GMM

Paper type Research paper

\section{Introduction}

Currently, globalization is a central research activity and remains an economic phenomenon that is increasingly debated. This phenomenon corresponds to a subject that can be criticized through its impact on national economies. Globalization has been frequently studied as part of the resulting economic integration of the interaction links between different markets. However, it justifies the relationship between the different countries of the world through the intensification of financial flows. One of the most perceptible phenomena of this globalization has been for several decades the observation of the sudden and spectacular increase in the mobility of capital, goods and people, thanks to more and more efficient transport networks and services.

The development of trade relations between economies urges the State to combine financial ties in order to enrich the role it has to play in the country and to promote the liberalization of international capital movements. The only certainty frequently encountered in the different markets is that they are characterized by instability; the crises are not fully controlled nor are the risks of their occurrence or expansion. We must fundamentally see the crucial role that can be played by the economic policies of countries, in particular countries in need of financing, as well as the management of public and private finances. This is essential and complicated because it questions the extent to which countries are able to direct financial flows to successful projects.

The State has to draw lessons as far as of the reaction of economic agents is concerned. It is about establishing an effective method for distinguishing between increasing financial flows and the debt challenge of countries, especially developing countries, and the constraints they impose, to track each country's experience. In improving the level of economic growth, the high growth of developing country debt poses a threat to the country's economy. Even though a lot of research has been carried out recently, the clear and decent debt threshold above which the economic growth of certain developing countries is jeopardize has not been established yet. There is clear evidence of a strong relationship between the debt trajectory and the performance of economic growth. The advent of financial flows - foreign direct investment (FDI), remittances and official development assistance - can be a key factor in the development of the economy.

From this standpoint, it is important for developing countries to strengthen their strategies for economic growth both in the short and long terms by providing a favorable climate in terms of infrastructure, investment and human development. In any case, it is necessary to stimulate the coordination of economic policies at both the national and international levels to trace sustained economic growth and urgent productive investment projects to improve sustainable development strategies. Indeed, a high economic growth can help improve the flow of FDI, remittances and sustained official development assistance. These flows are intended to finance sustainable development in many countries, particularly developing countries.

Financial flows can promote the sustainable development of countries, especially developing countries, taking into account the inadequacy of domestic resources. The main global flows that have emerged with globalization are the flows of capital, people and goods that have multiplied in recent decades. FDIs can lead to financial stability, promote sustainable development and also ensure the well-being of societies. They help developing countries to solve the problem of financing their economic activities, taking into consideration the inadequacy of domestic resources. Interest in is justified by their positive impact on productivity and economic growth. FDI Is considered to be one of the most appropriate sources for investment development as they can create jobs, transfer and develop new technologies and production capabilities, and help local businesses gain access to new international markets. 
Over the past two decades, developing countries have constantly increased their share of global foreign direct investment revenues. FDI is now one of the largest sources of external financing for developing countries. By involving a long-term relationship and lasting interests, FDI is often seen as a stable source of private international investment (OECD, 2016). Indeed, the phenomenon of labor migration is gradually increasing on a world scale. However, workers are looking for industrialized or oil-producing regions and countries. Indeed, the cultural and historical proximities determine these flows which are oriented towards the rich countries.

According to UNCTAD 2018, FDI flows to Africa amount to $\$ 42 \mathrm{bn}$ in 2017 , down $21 \%$ from 2016 (see Table 1). FDI flows to North Africa amounted to $\$ 13 \mathrm{bn}$ in 2017, a 4\% drop from 2016. FDI inflows to Morocco climbed to $\$ 2.7 \mathrm{bn}$, an increase of $23 \%$ compared to 2016.

FDI flows to Central Africa fell from $22 \%$ in 2016 to $\$ 5.7 \mathrm{bn}$ in 2017. FDI to West Africa accounts for $\$ 11.3 \mathrm{bn}$, an increase of $11 \%$.

FDI in Nigeria has fallen $21 \%$ from 2016 to $\$ 3.5 \mathrm{bn}$. FDI flows to East Africa, fell by $3 \%$ from 2016 to reach $\$ 7.6 \mathrm{bn}$ in 2017. FDI in Ethiopia decreased by $10 \%$ compared to 2016 , to $\$ 3.6 \mathrm{bn}$ in 2017. In Kenya, FDI increased by $71 \%$ to $\$ 672 \mathrm{~m}$. In South Africa, FDI accounts for $\$ 3.8 \mathrm{bn}$, a fall of $66 \%$. In South Africa, FDI inflows represent only $\$ 1.3 \mathrm{bn}$, a fall of $41 \%$ (Table 1 ).

Migrant remittances are the funds sent by people who live and work abroad to their home country, affecting the lives of many individuals around the world. The last two decades have seen a sharp increase in the amount of money transfers made by international migrants to developing countries, surpassing official development assistance (ODA) and more generally foreign aid. ODA is provided by donor states to improve the economic development and living standards of developing countries. ODA can take the bilateral route, provided directly by a donor to a recipient, or transit through a multilateral agency (UN, World Bank).

According to data from the World Bank (2018), migrant remittances to developing countries increased over the period 2009-2017 to 263,684 in 2017. Transfers decreased between 2015 due to political instability and some developing countries (see Figure 1).

According to the World Bank, total net ODA is broken down in 2016 as follows: SubSaharan Africa (\$44,293m), Middle East and North Africa $(\$ 25,696 \mathrm{~m})$, South Asia $(13,951$ millions of dollars), Latin America and the Caribbean $(\$ 11,390 \mathrm{~m})$, Eastern Europe and Central Asia $(\$ 9,712 \mathrm{~m})$, East Asia and the Pacific $(\$ 7,708 \mathrm{~m})$ (See Figure 2$)$.

The attractiveness of these three flows proves to be important for developing countries taking the need for financial resources for economic growth and development. An analysis of the present situation of FDI, remittances and official development assistance in developing countries is of particular interest. The rapid and important evolution of these flows to developing countries raises the question of their impact on the growth of recipient countries.

\begin{tabular}{lcc}
\hline Countries & Evolution in $\%$ & Incoming FDI in billions \$ \\
\hline Africa & -21 & 42 \\
North Africa & -4 & 13 \\
Morocco & 23 & 2.7 \\
West Africa & 11 & 11.3 \\
Nigeria & -21 & 3.5 \\
East Africa & -3 & 7.6 \\
Ethiopia & -10 & 3.6 \\
Kenya & 71 & 672 \\
Central Africa & -22 & 5.7 \\
South Africa & -66 & 3.8 \\
South Africa & -41 & 1.3
\end{tabular}

Effect of financial flows on economic growth

Source(s): CNUCED (2018), (www.unctad.org/fstatistics)

Table 1. Incoming FDI in Africa in 2017 


\section{PRR}

Figure 1.

Migrant remittances to developing countries (millions of dollars)

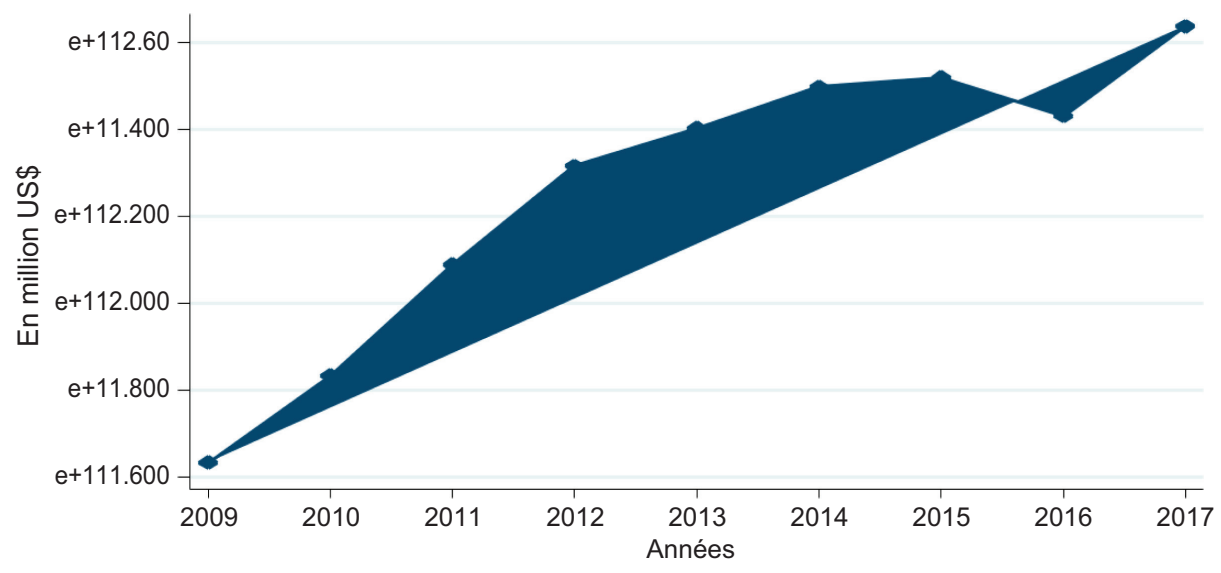

Source(s): Presented by authors Word bank (2017)

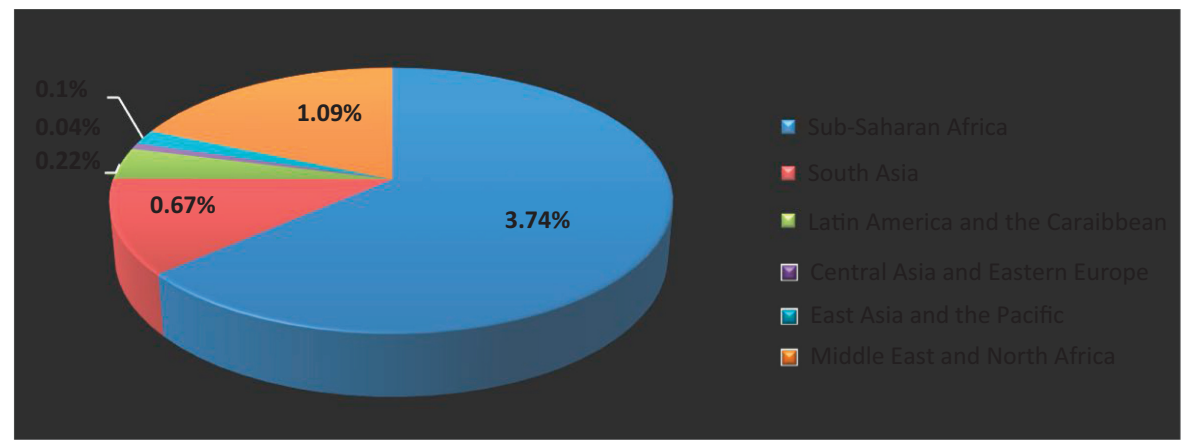

This article is empirically modeled on the effect of financial flows, namely FDI, remittances and official development assistance on economic growth by adopting the panel data methodology and focusing analysis on developing countries.

This article is structured as follows: the first section presents a review of the theoretical literature. The second section provides an overview of the empirical literature. The third section describes the empirical methodology adopted. The empirical tests, results and corresponding interpretations are presented in the fourth section.

\section{Theoretical literature review}

\subsection{The relationship between FDI and economic growth}

FDI is the largest component of capital inflows for developing countries. It plays an important role in world economic development. Second, FDI contributes to economic growth in developing countries in different channels. FDI gains the gap in financial resources for investment. Investors seek to gain in terms of proximity to raw materials or low labor costs.

Developing countries therefore benefit from new technologies and managerial knowledge. Thus, FDI can promote economic growth in developing countries. Makki and Somwaru (2004) report that FDI inflows are seen as an effective way to transfer technologies, knowledge and 
know-how from investing countries to developing countries. So, FDI flows can have positive effects on economic growth in developing countries through these channels.

\subsection{Remittances and economic growth: which transmission channels?}

Remittances are a potential source of economic growth in developing countries. It is therefore interesting to know how remittances are spent or invested.

2.2.1 Remittances and human capital. The relationship between remittances and human capital is mainly attributed to the income effect. Low-income households face financial constraints. They are unable to finance the schooling of their children and health expenses. The increase in household income through transfers pushes families to minimize the workload on their children, to allow as much time as possible for their studies (Acosta, 2006). In addition, school-aged children will generally benefit from higher future incomes and thus will provide more financial support to their elderly parents.

Yang (2008) showed that remittances have a positive impact on tuition fees in the Philippines. Therefore, the transfer of funds causes an increase in the annual expenditure on education of the household.

Tripati Rao et al. (2020) argued that developing economies in the South-East Asia region and South Asia need to invest more in human and physical capital in order to maintain a greater degree of trade integration and increase the effectiveness of official development assistance in order to divert the harmful effects of FDI and improve economic growth.

2.2.2 Remittances and physical capital. The relationship between migrant remittances and economic growth through the financial development channel can be explained in two different ways. On the one hand, the smooth functioning of financial markets, which reduces transaction costs, can help to direct remittances to projects that produce the highest profit and thus increase growth rates. In this case, we refer to the complementarity between remittances and the financial system. Das and Sethi (2019) find in his study that the effect of remittances on Sri Lanka's economic growth is very important. Economically, migrants' remittances increase family income and therefore, the level of domestic consumption.

Migrant remittances are positively associated with bank deposits and credit. More specifically, in countries with a low level of financial development which are generally developing countries, there are several difficulties in borrowing. When access to credit is limited, individuals can use remittances to free up such credit constraints. This would result in increased growth. Migrant remittances therefore can ease credit constraints and act as a substitute for an inefficient financial system. Therefore, financial development is an important channel for transmitting the impact of remittances from migrants on the growth of recipient countries. So, remittances have helped solve Sri Lanka's unemployment problem. This explains the positive effect of transfers on economic growth.

On the other hand, migrant remittances can compensate for a bad financial system in developing countries. There is therefore a substitution between remittances and the financial system. Remittances reduce liquidity constraints. Entrepreneurs can then use remittances whenever the financial system does not help them start productive activities due to lack of collateral or high loan costs.

\subsection{Does public aid to development promote economic growth?}

2.3.1 ODA and health care. The level of wealth of a country is important for health. ODA funds health programs. One of the Millennium Development Goals (MDGs) is the reduction of infant and child mortality. However, its realism is questioned with regard to a large part of the least developed countries. Moreover, its realism at the global and at the level of each country constitutes a very ambitious goal in the history of child mortality worldwide (Clemens et al., 2004).

In addition, official development assistance can reduce poverty and improve the health system. Das and Sethi (2019) find that official development assistance has a major role in

Effect of
financial flows
on economic
growth

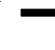


improving the level of economic growth. They announce that governments should strengthen the country's financial system and fight corruption.

2.3.2 ODA and international trade. Aid for trade is a financial and technical assistance to developing countries to help them build their capacity on the supply side. This allows these countries to develop their production and trade. Aid for trade facilitates the mobilization of international resources to reduce the bottlenecks of developing countries. It makes national political environments more favorable to exporters, contributes to the strengthening of national and regional institutions providing services to exporters and helps enterprises to become more competitive through the strengthening of trade-related infrastructure (Felicitas NowakLehmann et al., 2010). In addition, foreign aid promotes bilateral trade between the aid-giving recipient countries. Donor countries not only allocate financial capital to help developing countries formulate policies and regulations that stimulate trade and also provide preferential access to their markets (Kim, 2012). In contrary, Minasyan and Nunnenkamp (2016) argued that foreign aid does not lead to any improvement in the infrastructure, institutions and economic growth of the recipient country because of corruption. This discourages migrants from sending funds to and investing in their home countries. Aid is effective in countries that are well structured institutionally and have a strong political environment.

\section{Empirical literature review}

The influence of FDI on economic growth varies from one country to another. For example, $\mathrm{Xu}(2000)$ showed that for some countries FDI has a negative impact on GDP growth. In order to study the interaction between FDI and GDP, Alalaya (2010) used the cointegration-based ARDL model for the Jordan case from 1990 to 2008. The results indicate unidirectional causality. In the other hand, Coon and Neumann (2015) studied the relationship between remittances and FDI in 118 developing countries from 1980 to 2010 and found that an increase of $10 \%$ in FDI inflows corresponds to a $3.6 \%$ increase in remittances. Such results suggest that migrant remittances and FDI are complementary. Remittances increase with a large inflow of FDI providing development finance to countries that send a significant number of migrants abroad. Remittances increase FDI by providing relevant information and reducing uncertainty. However, migrants can orient their income toward national investments or through FDI flows by positively impacting the economy of their native countries.

Recently, Nguyen (2017) studies the short- and long-term effects of FDI on Vietnam's economic growth over the period 1986-2015, using the ARDL model. The results lead to significant and positive long-term effects and insignificant relationships in the short term.

Several studies have highlighted the evidence of a positive effect of public development aid on economic growth (Karras, 2006). Cungu and Swinnen (2003) used the fixed effects model to study the impact of aid on growth. Their results indicate evidence of a positive effect of aid on economic growth.

Other studies claim that foreign aid has negative effects on the economic development of recipient countries. For example, Sothan (2018) studies the effect of foreign aid on Cambodia's economic growth over the period 1980-2014, using the linear ARDL model. He found that foreign aid has a significant negative impact on long-term economic growth. These negative results are coherent with several past and recent studies (Rajan and Subramanian, 2008; Ali and Isse, 2005).

There is evidence in the literature that the relationship between economic growth and remittances is generally positive. In fact, Williams (2018) used a panel of 109 countries to study the effect of remittances on economic growth. He found that migrant remittances have a positive effect on economic growth in well-governed countries. Javaid (2017) examined the effect of external capital flows (remittances, FDI and ODA) on Pakistan's GDP growth over the period 1973-2014. The results suggest that FDI and ODA had overall significant and positive impact on Pakistan's GDP growth in both the short and long terms. Remittances play no significant role in explaining the variations in Pakistan's economic growth. According to the 
author, the relationship between remittances and economic growth can be explained by the fact that the former are used for consumption to increase well-being rather than to improve overall economic growth. In addition, a large flow of remittances can negatively impact growth, given that participation in the labor market is negligible. Another reason for the negative impact of migrants' remittances on economic growth is the unproductive use of these flows.

Recently, Ukhtiyani and Indartono (2020) studied the effect of migrant remittances and official development assistance on Indonesia's economic growth. Their results show that migrants' funds are channeled towards food expenditure. In addition, Indonesia is characterized by the absence of effective infrastructure, which discourages foreign investors.

\section{Data and empirical methodology}

We seek to study the effect of foreign direct investment, remittances and ODA and some control variables i.e. domestic credit, life expectancy, gross fixed capital formation (GFCF), inflation and three institutional factors on economic growth in developing countries by adopting the panel data methodology. Then, we will discuss empirical tests to assess the econometric relevance of the model specification before presenting the analysis of the results and their interpretations that lead to economic policy implications.

As part of this work, we have rolled panel data for developing countries at an annual frequency during the period from 1990 to 2016. In a first stage of empirical analysis, we will carry out a technical study of the heterogeneity test of the individual fixed effects of the countries. This kind of analysis makes it possible to identify the problems retained in the specific choice of econometric modeling to be undertaken in the specificities of the panel data.

\subsection{Presentation of variables}

In this empirical analysis, the following dependent variable is used:

The GDP growth rate per capita of country $i$ at date $t$. These are 41 developing countries during a period ranging from 1990 to 2016 following an annual data frequency. The data are taken from the site (http://www.WDI.tn).

The matrix of the variables of interest is composed of the following explanatory variables: FDI: The stock of foreign direct investment as a percentage of GDP. All FDI data are extracted from the UNCTAD database (2017).

TR: Migrant remittances are as a percentage of GDP. All data on migrant remittances are taken from the World Bank's "World Development Indicators (2017)" database.

ODA: net official development assistance is measured against GNP. All data on ODA are taken from the World Bank's World Development Indicators (2017) database.

DC: We use domestic credit as a percentage of GDP to measure financial development. The data are taken from the World Bank's "World Development Indicators (2017)" database.

LE: Life expectancy at birth is used as a proxy measure of human development and quality of life. The data are taken from the World Bank's "World Development Indicators (2017)" database.

GFCF: Gross fixed capital formation is measured as a percentage of GDP as an approximation of domestic investment. The data are taken from the World Bank's "World Development Indicators (2017)” database.

Inflation rate: It is measured by the GDP deflator (Nguyen P.H). The increase in inflation reduces the purchasing power of agents. Inflation data are taken from the World Bank's "World Development Indicators (2017)" database. 
BQ: The bureaucratic quality variable is considered an approximation of institutional quality. Bureaucratic quality data are extracted from the database (International Country Risk Guide (ICRG), 2017).

GS: Government stability is an approximation of institutional quality. The data are extracted from the database (International Country Risk Guide, (ICRG)).

LO: The law and order variable are considered as an approximation of institutional quality.

The data are extracted from the database (International Country Risk Guide, (ICRG)).

\subsection{Specification of considered models}

The ultimate objective of this empirical analysis is to study the effect of financial flows on economic growth measured by the growth rate of GDP per capita. A global sample of 41 developing countries and three sub-samples are considered, namely low-income countries, lower-middle-income countries and upper-middle-income countries. The income classification is deducted from the World Bank for 2017 and permits to classify countries to be grouped in terms of their levels of development. This classification allows classifying the countries by priority according to the need for external sources of financing such as the official development assistance, the FDI and remittances. Moreover, it helps to give the governments of developing countries a more detailed view in terms of the impact of each flow on economic growth in order to apply the appropriate economic policies. The classification of countries by income is presented in the Appendix.

To do this, we consider a dynamic approach based on panel data in order to specify between individual fixed and random effects, and subsequently, the generalized method of moments that makes it possible to overcome the problems of endogeniety. Specifically, we want to identify and capture the effect of financial flows on economic growth. Model (1) for the global sample of countries is as follows:

$$
\begin{aligned}
& \text { GDP per capita }_{i t}=\beta_{0}+\beta_{1} \ln (\mathrm{FDI})_{i t}+\beta_{2} \ln (\mathrm{PR})_{i t}+\beta_{3} \mathrm{ODA}_{i t}+\beta_{4} \mathrm{DC}_{i t}+\beta 5 \ln (\mathrm{LE})_{i t} \\
& +\beta_{6} \ln (\mathrm{GFCF})_{i t}+\beta_{7} \text { inflation }_{i t}+\beta_{8} \mathrm{BQ}_{i t}+\beta_{9} \mathrm{GS}_{i t}+\beta_{10} \mathrm{LO}_{i t}+\varepsilon_{i t}
\end{aligned}
$$

With $i=1, \ldots, 41$ is the number of countries considered in the sample chosen, $T=1990, \ldots$ 0.2016 is the period of the study. $(\cdot)$ Corresponds to the individual specific effect of fixed or random nature, $\left(\varepsilon_{i t}\right)$ is the error term and $\beta_{1}, \beta_{2}, \beta_{3}, \beta_{4}, \beta_{5}, \beta_{6}, \beta_{7}, \beta_{8}, \beta_{9}$, and $\beta_{10}$ are parameters to estimate.

Model (2) for low-income countries is written as:

$$
\mathrm{GDP}_{\text {per capita }}{ }_{i t}=\alpha_{0}+\alpha_{1} \ln (\mathrm{FDI})_{i t}+\alpha_{2} \ln (\mathrm{PR})_{i t}+\alpha_{3} \mathrm{ODA}_{i t}+\varepsilon_{i t}
$$

With $i=1, \ldots, 8$ is the number of countries considered in the sample of low-income countries.

$=1990 \ldots 0.2016 .\left(\varepsilon_{i t}\right)$ is the error term and $\alpha_{1}, \alpha_{2}, \alpha_{3}$ are parameters to be estimated. Model (3) for lower-middle-income countries is:

$\mathrm{GDP}_{\text {percapita }}{ }_{i t}=\gamma_{0}+\gamma_{0} \ln (\mathrm{FDI})_{i t}+\gamma_{2} \ln (\mathrm{PR})_{i t}+\gamma_{3} \mathrm{ODA}_{i t}+\gamma_{4} \ln (\mathrm{GFCF})+\gamma_{5}$ inflation $_{i t}+\varepsilon_{i t}$

Upper-middle-income country model (4) is in the form of:

$$
\mathrm{GDP}_{\text {per capita }}=\delta_{0}+\delta_{1} \ln (\mathrm{FDI})_{i t}+\delta_{2} \ln (\mathrm{PR})_{i t}+\delta_{3} \mathrm{ODA}_{i t}+\delta_{4} \ln (\mathrm{GFCF})+\varepsilon_{i t}
$$




\subsection{Empirical results}

Tables 2-5 report the results of the OLS regression, fixed effect and random effect models. Considering the global sample of developed countries, we notice that the Fisher statistic associated with the homogeneity test is significant at the $1 \%$ threshold, which indicates the existence of heterogeneity in panel. Thereafter, it is necessary to check whether the individual effect is fixed or random by the use of use of the Hausman test. In other words, to collect the individual effect with the constant or collect it with the error term. From the results reported in Table 2 and specifically the Hausman test statistic, it is assumed that the estimates for the model (1) studied will be those of the individual fixed effect models. We observe a probability equal to zero. Thus, the Hausman test rejects the hypothesis of no correlation between the explanatory variables and the error term.

To test for heteroskedasticity on panel data, the Breuch-Pagan test is carried out in four progressive steps: recovering the regression residuals, generating the residue square, making a squared regression of the residuals on the independent variable of initial regression and finally test if the coefficients are jointly significant to find the LM test. The significance of the coefficients leads us to detect the presence of heteroscedasticity. The results of this test and

\begin{tabular}{lccc}
\hline Variables & OLS & Fixed effect & Random effect \\
\hline $\ln (\mathrm{FDI})$ & -0.1032 & -0.0463 & -0.0615 \\
$P$-value & 0.4200 & 0.8140 & 0.7040 \\
$\ln (\mathrm{PR})$ & 0.0528 & 0.1097 & 0.0944 \\
$P$-value & 0.4720 & 0.4450 & 0.3860 \\
ODA & $-0.031^{* * *}$ & $-0.0620^{* *}$ & $-0.0516^{* * *}$ \\
$P$-value & 0.0840 & 0.0260 & 0.0300 \\
DC & $0.0068^{* * *}$ & $-0.0359^{*}$ & $-0.0122^{* * *}$ \\
$P$-value & 0.0840 & 0.0000 & 0.0380 \\
$\ln (\mathrm{LE})$ & 0.2521 & 4.3769 & 2.2424 \\
$P$-value & 0.8310 & 0.1360 & 0.2340 \\
$\ln (\mathrm{GFCF})$ & $2.3075^{*}$ & $2.6886^{*}$ & $2.5767^{*}$ \\
$P$-value & 0.0000 & 0.0000 & 0.0000 \\
INFLATION & $-0.0011^{* *}$ & $-0.0012^{*}$ \\
$P$-value & $0.0013^{*}$ & 0.0150 & 0.0070 \\
BQ & 0.0060 & -0.2898 & -0.2820 \\
$P$-value & -0.1876 & 0.1570 & 0.1310 \\
GS & 0.2310 & $0.1201^{* * *}$ & $0.1309^{* *}$ \\
$P$-value & $0.1435^{* *}$ & 0.0520 & 0.0330 \\
LO & 0.0230 & 0.1972 & $0.2665^{* * *}$ \\
$P$-value & $0.2551^{* *}$ & 0.2320 & 0.0710 \\
CONSTANTE & 0.0350 & $-23.0399^{* *}$ & $-15.1769^{* *}$ \\
$P$-value & -7.1400 & 0.0460 & 0.0390 \\
\hline
\end{tabular}

Diagnostics

$R$ squared

0.0096

9.2700*

0.0000

Prob

Hausman test

$20.5100 * *$

Prob

0.0150

$5.9330 * *$

Wooldridge test

Prob

Heteroscedasticity 0.0194

Prob

4115.46*

0.0000
Effect of financial flows on economic growth

Note(s): *,** and *** indicate the signification at 1, 5 and $10 \%$ threshold

Table 2

Results of fixed and random effect models (global sample) 


\section{PRR}

\begin{tabular}{|c|c|c|c|}
\hline Variables & OLS & Fixed effect & Random effect \\
\hline $\ln (\mathrm{FDI})$ & 0.4158 & 0.2888 & 0.3327 \\
\hline$P$-value & 0.1390 & 0.3950 & 0.2940 \\
\hline $\ln (\mathrm{PR})$ & 0.0076 & -0.1689 & -0.1172 \\
\hline$P$-value & 0.982 & 0.7030 & 0.7700 \\
\hline ODA & 0.0146 & -0.0347 & -0.0194 \\
\hline$P$-value & 0.612 & 0.3240 & 0.5530 \\
\hline CONSTANTE & -0.0700 & 1.1255 & 0.7484 \\
\hline$P$-value & 0.943 & 0.3290 & 0.5430 \\
\hline \multicolumn{4}{|l|}{ Diagnostics } \\
\hline \multicolumn{3}{|l|}{$R$ squared } & 0.0035 \\
\hline \multicolumn{3}{|l|}{ Fisher test } & 1.9300 \\
\hline \multicolumn{3}{|l|}{ Prob } & 0.5870 \\
\hline \multicolumn{3}{|l|}{ Hausman test } & 1.5600 \\
\hline \multicolumn{3}{|l|}{ Prob } & 0.6694 \\
\hline \multicolumn{3}{|l|}{ Wooldridge test } & 0.0300 \\
\hline \multicolumn{3}{|l|}{ Prob } & 0.8678 \\
\hline \multicolumn{3}{|l|}{ Heteroscedasticity } & $10.1500^{*}$ \\
\hline \multicolumn{3}{|l|}{ Prob } & 0.0007 \\
\hline Note(s): *indicates & $n$ at $1 \%$ & & \\
\hline
\end{tabular}

Results of fixed and random effect models (low-income countries)

Note(s): *indicates the signification at $1 \%$ threshold

\begin{tabular}{lccc}
\hline Variables & OLS & Fixed effect & Random effect \\
\hline $\ln (\mathrm{FDI})$ & -0.0647 & -0.1405 & -0.0627 \\
$P$-value & 0.6730 & 0.5720 & 0.7440 \\
$\ln (\mathrm{PR})$ & 0.0954 & 0.1530 & 0.1186 \\
$P$-value & 0.4160 & 0.4000 & 0.4210 \\
ODA & $-0.1537^{*}$ & $-0.1078^{* * *}$ & $-0.1249^{* *}$ \\
$P$-value & 0.0000 & 0.0620 & 0.0120 \\
ln(GFCF) & $2.1770^{*}$ & $3.5206^{*}$ & $2.6484^{*}$ \\
$P$-value & 0.0000 & 0.0000 & 0.0000 \\
INFLATION & -0.0073 & $-0.0343^{*}$ & $-0.0240^{* *}$ \\
$P$-value & 0.4310 & 0.0010 & 0.0150 \\
CONSTANTE & $-3.5090^{* *}$ & $-7.1855^{*}$ & $-4.8437^{*}$ \\
$P$-value & 0.0110 & 0.0010 & 0.0050 \\
\hline Diagnostics & & & 0.1507 \\
\hline$R$ squared & & & $11.0700^{*}$ \\
Fisher test & & & 0.0000 \\
Prob & & & $0.3800^{*}$ \\
Hausman test & & 0.0011 \\
Prob & & 0.4849 \\
Wooldridge test & & $2132.98^{*}$ \\
Prob & & 0.0000 \\
Heteroscedasticity & & \\
Prob & & \\
Note(s) $*$, ** and $* * *$ indicate the signification at 1,5 and $10 \%$ threshold & \\
& & &
\end{tabular}




\begin{tabular}{|c|c|c|c|c|}
\hline Variables & OLS & Fixed effect & Random effect & $\begin{aligned} \text { Effect of } \\
\end{aligned}$ \\
\hline $\ln (\mathrm{FDI})$ & 0.1191 & -0.0910 & -0.0427 & on economic \\
\hline$P$-value & 0.6600 & 0.8020 & 0.8960 & \\
\hline $\ln (\mathrm{PR})$ & 0.0609 & 0.1381 & 0.1174 & growth \\
\hline$P$-value & 0.6550 & 0.5530 & 0.5410 & \\
\hline ODA & -0.1712 & -0.1600 & -0.1412 & \\
\hline$P$-value & 0.3800 & 0.6160 & 0.5960 & \\
\hline $\ln (\mathrm{GFCF})$ & $5.2517^{*}$ & $3.7127^{*}$ & $4.2563^{*}$ & \\
\hline$P$-value & 0.0000 & 0.0000 & 0.0000 & \\
\hline CONSTANTE & $-13.9754^{*}$ & $-8.4420 * *$ & $-10.3251^{*}$ & \\
\hline$P$-value & 0.0000 & 0.0110 & 0.0000 & \\
\hline \multicolumn{5}{|l|}{ Diagnostics } \\
\hline \multicolumn{3}{|l|}{$R$ squared } & 0.5024 & \\
\hline \multicolumn{3}{|l|}{ Fisher test } & $24.6600 *$ & \\
\hline \multicolumn{3}{|l|}{ Prob } & 0.0001 & \\
\hline \multicolumn{3}{|l|}{ Hausman test } & 2.3800 & \\
\hline \multicolumn{3}{|l|}{ Prob } & 0.6670 & \\
\hline \multicolumn{3}{|l|}{ Wooldridge test } & $19.939 *$ & Table 5 \\
\hline \multicolumn{3}{|l|}{ Prob } & 0.0005 & Results of fixed and \\
\hline \multicolumn{3}{|l|}{ Heteroscedasticity } & $41.2000 *$ & random effect models \\
\hline \multirow{2}{*}{\multicolumn{4}{|c|}{$\begin{array}{l}\text { Prob } \\
\text { Note(s): * and ** indicate the signification at } 1 \% \text { and } 5 \% \text { threshold }\end{array}$}} & (upper-middle-income \\
\hline & & & & countries) \\
\hline
\end{tabular}

for the two regressions are reported in Table 2. From these results, we conclude that the errors are heteroscedastic since the probability is less than 1 and $5 \%$. With respect to autocorrelation, the Wooldridge test which is statistically significant at the $5 \%$ threshold was used and thus the presence of autocorrelation of errors is proved.

Looking at Table 2 and considering per capita GDP as dependent variable, we find that the effect of FDI on economic growth is negative and insignificant. However, fund transfers affect economic growth positively and in a nonsignificant way. It is noted that the effect of official development assistance on growth is negative and significant. For other key determinants of economic growth, the effects are ambiguous. They are negative and insignificant or positive and significant.

For the low-income sample (Table 3), it is assumed that the effect of FDI on economic growth is positive and not significant. However, migrant remittances and official development assistance affect growth negatively and in a nonsignificant way. We carry out the specification test of Hausman (1978). It is a test of specification of the individual effects which makes it possible to arbitrate between the choice of the model with fixed effects and the model with random effects. The hypothesis tested concerns the correlation between the individual effects and the explanatory variables. Under the null hypothesis, the model can be specified with random individual effects. Under the alternative hypothesis, the model must be specified with fixed individual effects and then the within estimator must be retained.

According to Table 3, the results of the Hausman test show that the null hypothesis of no correlation between the random term and the explanatory variables is accepted since the $p$-value is not significant at the $10 \%$ threshold. Thus, the random effects model best represents the data structure of our sample because it is more suitable than the fixed effects model. The Lagrange multiplier test of Breusch-Pagan strongly rejects the existence of a fixed effect model and accepts the alternative hypothesis, which asserts the choice of the random effect model in our estimation. As a conclusion, random individual effects should be introduced into the model, confirmed by the Hausman specification test and the Lagrange test. 
Looking at the results of the estimates for lower-middle-income countries (Table 4), we notice that the impact of FDI on economic growth is negative and insignificant. However, transfers affect growth positively but in a nonsignificant way. On the other hand, the effect of public support on growth is negative and significant. It is noted that gross fixed capital formation positively affects economic growth. However, the effect of inflation is negative and significant.

The results of the Hausman test show that the null hypothesis of no correlation between the random term and the explanatory variables is rejected since the $p$-value is significant at the $1 \%$ threshold. Thus, the fixed effects model best represents the data structure of our sample because it is more suitable than the random effects model. The Breusch-Pagan Lagrange Multiplier (ML) test (Random Effect Expression Test) strongly accepts the existence of a fixed effect model and rejects the alternative hypothesis, which asserts the choice of effect model fixed in our estimation.

Ultimately, and for higher middle-income countries (Table 5), the effect of FDI as well as official development assistance on growth is negative and insignificant. However, transfers affect economic growth positively but in a nonsignificant way. It is noted that the effect of gross fixed capital formation on growth is positive and statistically significant.

The results of the Hausman test show that the null hypothesis of no correlation between the random term and the explanatory variables is accepted since the $p$-value is not significant at the $10 \%$ threshold. Thus, the random effects model best represents the data structure of our sample because it is more suitable than the fixed effects model. The Breusch-Pagan Lagrange Multiplier (ML) test strongly rejects the existence of a fixed effect model and accepts the alternative hypothesis, which asserts the choice of the random effect model in our estimation.

In order to overcome the problems of simultaneity and inverse causality and for the purpose of improving the statistical significance of the expected effects, two estimation techniques were used, namely the difference GMM method and the GMM method in the system that takes into account the effect of the constant in the models studied. On reading the results reported in Tables 6-9, we find that the Sargan test applied to the endogenous

\begin{tabular}{lrr}
\hline Variables & & \\
\hline GDP per capita $(-1)$ & $0.1509^{*}(0.0000)$ & GMM as a system \\
$\ln (\mathrm{FDI})$ & $4.4531^{*}(0.0010)$ & $0.1597^{*}(0.0000)$ \\
$\ln (\mathrm{PR})$ & $-1.9471(0.1570)$ & $1.6505^{* *}(0.0140)$ \\
ODA & $-0.1788^{*}(0.0000)$ & $2.1890^{* *}(0.0180)$ \\
DC & $-0.1008^{*}(0.0000)$ & $-0.0584^{* *}(0.0150)$ \\
$\ln (\mathrm{LE})$ & $-19.8029(0.1080)$ & $-0.0220^{* * *}(0.0810)$ \\
$\ln (\mathrm{GFCF})$ & $2.0737^{* * * *}(0.0560)$ & $-8.5266^{*}(0.0080)$ \\
INFLATION & $0.0010^{* * * *}(0.0830)$ & $3.0907^{*}(0.0010)$ \\
BQ & $1.2163^{*}(0.0010)$ & $0.0044^{*}(0.0010)$ \\
GS & $0.6334^{* *}(0.0190)$ & $0.6268^{* * *}(0.0670)$ \\
LO & $0.2794(0.4530)$ & $0.7487^{*}(0.0020)$ \\
Constante & & $0.1596(0.5340)$ \\
\hline Diagnostics & & $15.6005(0.1880)$ \\
\hline AR(1) & & $-4.4400^{*}(0.0000)$ \\
AR(2) & & $0.2900(0.7690)$ \\
Sargan $t$-test & $-4.3700^{*}(0.0000)$ & $18.9300(0.6500)$ \\
Hansen $t$-test & $0.3900(0.6970)$ & $23.3400(0.3830)$ \\
Note(s): $*$, $*$ and $* * *$ indicate the signification at 1,5 and $10 \%$ threshold &
\end{tabular}

Table 6.

GMM as a difference and GMM as a system (global sample)

Note(s): *** and *** indicate the signification at 1,5 and $10 \%$ threshold 
Variables

GMM as a difference

GDP per capita $(-1)$
$\ln (\mathrm{FDI})$
$\ln (\mathrm{PR})$
ODA

Constante

$-0.0356(0.3090)$
$0.5385(0.5110)$
$-3.2203(0.2290)$
$-0.1048 *(0.0080)$

$-0.0356(0.3090)$

$-3.2203(0.2290)$

$-0.1048 *(0.0080)$
GMM as a system

$0.0160(0.8250)$

$3.4005 * * *(0.0990)$

$-6.8875^{* * * *}(0.0930)$

$-0.5907 * * *(0.0950)$

$13.6452 * * *(0.0890)$

Effect of financial flows on economic growth

Diagnostics

\begin{tabular}{lrr}
\hline $\operatorname{AR}(1)$ & $-2.4900 * *(0.0130)$ & $-2.4500^{* *}(0.0140)$ \\
$\mathrm{AR}(2)$ & $-0.2700(0.7890)$ & $0.2200(0.8280)$ \\
Sargan $t$-test & $4.0700(0.6680)$ & $4.6100(0.7070)$ \\
Hansen $t$-test & $5.5900(0.4710)$ & $1.6500(0.9770)$ \\
Note(s): $* * *$ and $* * *$ indicate the signification at 1,5 and $10 \%$ threshold &
\end{tabular}

Note(s): *, ** and *** indicate the signification at 1,5 and $10 \%$ threshold

Table 7.

GMM as a difference and GMM as a system (low-income countries)

\section{Variables}

\begin{tabular}{l}
\hline GDP per capita $(-1)$ \\
$\ln (\mathrm{FDI})$ \\
$\ln (\mathrm{PR})$ \\
ODA \\
$\ln (\mathrm{GFCF})$ \\
INFLATION \\
Constante
\end{tabular}

GMM as a difference

$$
\begin{array}{r}
-0.2904 *(0.0090) \\
-6.4677(0.2430) \\
0.2042(0.5900) \\
-0.1376(0.3180) \\
18.8277 *(0.0000) \\
0.0262(0.4180)
\end{array}
$$

GMM as a system

$-0.0529(0.2170)$

$-4.0861 * *(0.0320)$

$1.0751 *(0.0000)$

$-0.1912(0.1080)$

$3.7754 * *(0.0360)$

$0.1045 * * *(0.0700)$

$0.4029(0.9580)$

Diagnostics

\begin{tabular}{lrr}
\hline $\operatorname{AR}(1)$ & $-1.8300^{* * *}(0.0670)$ & $-2.2900^{* *}(0.02200)$ \\
AR(2) & $-0.9900(0.3210)$ & $-0.6100(0.5440)$ \\
Sargan $t$-test & $5.1500(0.6410)$ & $8.4100(0.3940)$ \\
Hansen $t$-test & $6.8100(0.4490)$ & $6.9800(0.5390)$
\end{tabular}

Note(s): *, ** and *** indicate the signification at 1,5 and $10 \%$ threshold

Table 8 .

GMM as a difference and GMM as a system (lower-middle-income countries)

\begin{tabular}{lrr}
\hline Variables & GMM as a difference & GMM as a system \\
\hline GDP per capita $(-1)$ & $0.4481^{*}(0.0000)$ & $0.6848^{*}(0.0080)$ \\
$\ln (\mathrm{FDI})$ & $-4.4143^{*}(0.0080)$ & $1.1936^{* *}(0.0490)$ \\
$\ln (\mathrm{PR})$ & $1.5687(0.1020)$ & $-0.0338(0.8230)$ \\
ODA & $-5.340^{*}(0.0020)$ & $-4.1018^{*}(0.0030)$ \\
$\ln (\mathrm{GFCF})$ & $-3.3431(0.4580)$ & $-9.4004^{* *}(0.0220)$ \\
Constante & & $29.1939^{*}(0.0250)$ \\
\hline
\end{tabular}

Diagnostics

$\begin{array}{lrr}\mathrm{AR}(1) & -2.8200 *(0.0050) & -2.4800^{*}(0.0130) \\ \mathrm{AR}(2) & 0.0100(0.9940) & 0.4600(0.6430) \\ \text { Sargan } t \text {-test } & 6.8500(0.9620) & 8.6500(0.9270) \\ \text { Hansen } t \text {-test } & 10.9400(0.7570) & 9.4300(0.8950)\end{array}$

Note(s): * and ** indicate the signification at $1 \%$ and $5 \%$ threshold

Table 9.

GMM as a difference and GMM as a system (upper-middle-income countries) 
variable and that of Hansen applied to the exogenous variable make it possible to accept the instrument validity assumption for the global sample of countries and the three sub-samples considered, i.e. the instrument is highly correlated with the endogenous variable but is not correlated with the error term. It is assumed that the $p$-values associated with the two tests are not significant at the different 1 and $5 \%$ thresholds. In addition, the Arellano and Bond autocorrelation tests indicate the absence of a second-order correlation of the residuals with a nonsignificant probability for the different regression models considered.

Reading the results reported in Table 6 and considering the GMM as a system, it is assumed that the effect of FDI as well as transfers on economic growth is positive and statistically significant. The effect of transfers is confirmed by Williams (2018). On the other hand, the effect of official development assistance on growth is negative and significant. This is justified by the works of Sothan (2018). It is noted that the effects of domestic credit and life expectancy are negative and significant. In addition, institutional factors affect economic growth positively and significantly with the exception of the factor (LO).

Considering low-income countries (Table 7), there is an ambiguous effect of financial flows on economic growth. Indeed, the impact of FDI on economic growth is positive and significant. It is noted that transfers as well as public aid affect growth in a negative and significant way.

For lower-middle-income countries (Table 8), the impact of FDI on economic growth is negative and statistically significant. However, the effect of transfers on growth is positive and significant. On the other hand, official development aid has a negative effect on growth and in a nonsignificant way. Note that the effects of gross fixed capital formation and inflation on growth are positive and significant.

Ultimately, for upper-middle-income countries (Table 9), there is a positive and significant effect of FDI on economic growth. However, the effect of government support and gross fixed capital formation on growth is negative and significant. On the other hand, transfers affect economic growth in a negative and insignificant way. So, the effects are ambiguous.

\section{Conclusion and policy implications}

The general interest of this work is to focus on international financial flows and the economic growth of developing countries. The econometric methodology used is based on the panel data using two complementary approaches namely the static panel and the dynamic panel whose interest is to solve the problems of endogeniety due essentially to the problems of simultaneity and inverse causality.

The empirical results validate the hypotheses put forward and indicate the evidence of an ambiguous effect of financial flows on economic growth. The empirical findings from this analysis suggest the use of economic-type solutions to resolve some of the shortcomings encountered in terms of unexpected effects. Governments in these countries should improve the business environment by establishing a framework that further encourages domestic and foreign investment.

The results of our estimates validate the hypotheses we have advanced. The three international financial flows have a mixed effect on the economic growth of developing countries. Such results urge developing countries governments to put in place economic recommendations according to FDI structure (horizontal or vertical) in order to encourage foreign and domestic investment. FDI inflows can force the closure of some small businesses, due to competitive pressure, or the withdrawal of planned investments. Governments of developing countries should highlight economic policies taking into account the structure of FDI in order to crowd out the eviction consequences which is explained by the dominance of foreign investment in favor of domestic investment, and vice versa. 
If the effect of transfers on economic growth is positive, so migrant funds can increase family health and education expenses and promote entrepreneurship.

If the effect of remittances on economic growth is no significance, so remittances from migrants are often transferred through informal channels, for example through friends or family members traveling abroad. In other words, remittances of migrants to developing countries take place through informal channels. This therefore poses a major challenge for developing countries to develop the financial system in terms of cost and encourage migrants to send their funds through formal channels. Indeed, governments should set up policies that encourage the transfer of funds to the formal channels by lowering the transfer costs and by offering more information on the entrepreneurial spirit.

In addition, developing countries need to improve their governance to better manage the aid received. The aim of ODA is to promote development in developing countries at different levels: social, economic, cultural, and so forth. But, in most cases, this aid is not appropriately used due to corruption or ill management. The result is therefore disastrous.

Likewise, loans from the IMF or the word bank are supposed to foster economic, industrial, agricultural and social growth. Rarely is the objective achieved as offend times these loans evaporate and no one knows low and where or they are used not to create investments and new jobs but to pay back high previous debts. In this case, the country is caught in a vicious circle and the results are negative and not significant.

Therefore, governments in developing countries have to think of efficient policies in order to have clear objectives and targets. This can be attained if corruption is eliminated and efficient competent managers are appointed to take care of economic growth. Official development assistance works in well-governed countries. However, this result can be explained by the dependence of some developing countries for assistance. As a result of receiving a lot of aid flow, developing countries, especially the poorest or low-income ones, have become very dependent. Economic growth in developing countries has weakened, despite massive official development assistance flows. Official development assistance therefore pushes developing countries to be linked to the famous trap "Debt trap" (Mallik, 2008). In addition, several developing countries are characterized by corruption or mismanagement of foreign aid received and bad governance. However, in reality, some of these official development assistance funds are diverted for purely personal ends instead of carrying out investment projects due to the low level of savings in some developing countries. Official development assistance therefore effectively promotes economic growth only in a good political environment. This result proves that developing countries are not wellgoverned. Ultimately, official development assistance received by some developing countries is intended for humanitarian reasons, including the aim of managing food crises and natural disasters, and therefore cannot promote economic growth in an effective manner.

ODA and remittances can have a positive effect and save developing countries from their economic decline only if they are efficiently used and this seems hard to achieve as such countries suffer from so many social problems.

\section{References}

Acosta, P. (2006), "Labor supply, school attendance, and remittances from international migration: the case of El Salvador", World Bank Policy Research Working Paper Series, No. 3903, p. 57.

Alalaya, M.M. (2010), “ARDL models applied for Jordan trade, FDI and GDP series”, European Journal of Social Sciences, Vol. 13 No. 4, pp. 605-616.

Ali, A.M. and Isse, H.S. (2005), "An empirical analysis of the effect of aid on growth", International Advances in Economic Research, Vol. 11 No. 1, pp. 1-11.

Clemens, M., Kenny, C. and Moss, T. (2004), "The trouble with the MDGs: confronting expectations of aid and development success", Center for Global Development Working Paper \#40. 
Coon, M. and Neumann, R. (2015), Follow the Money: Remittance Responses to FDI Inflows, Munich Personal REPEC Archive (MPRA).

Cungu, A. and Swinnen, J.F.M. (2003), "The impact of aid on economic growth in transition economies: an empirical study", Discussion Papers 128/03, Centre for Institutions and Economic Performance, Katholieke Universiteit Leuven.

Das, A. and Sethi, N. (2019), "Effect of foreign direct investment, remittances, and foreign aid on economic growth: evidence from two emerging South Asian economies", Journal of Public Affairs, Vol. 20 No. 3, p. e2043, doi: 10.1002/pa.2043.

Felicitas Nowak-Lehmann, D., Martinez-Zarzoso, I., Cardozo, A. and Klasen, S. (2010), "Foreign aid and recipient countries' exports: how important are improved bilateral trade relations?", Econstor, No. 44, pp. 1-39.

Javaid, W. (2017), "Impact of remittances on consumption and investment. Case study of Tehsil Sargodha, Punjab, Pakistan”, Journal of Finance and Economics, Vol. 5 No. 4, pp. 156-163.

Karras, G. (2006), "Foreign aid and long-run economic growth: empirical evidence for a panel of developing countries", Journal of International Development, Vol. 18 No. 7, pp. 15-28.

Kim, Y.R. (2012), "The effect of aid for trade on export diversification of recipient countries", Paper Prepared for ETSG 2013 Birmingham, 15th Annual Conference.

Makki, S.S. and Somwaru, A. (2004), "Impact of foreign direct investment and trade on economic growth; evidence from developing countries", American Journal of Agricultural Economies, Vol. 86 No. 3, pp. 795-801.

Mallik, G. (2008), "Foreign aid and economic growth: a cointegration analysis of the six poorest African countries", Economic Analysis and Policy, Vol. 38, pp. 251-260.

Minasyan, A. and Nunnenkamp, P. (2016), "Remittances and the effectiveness of foreign aid", Review of Development Economics, Vol. 20 No. 3, pp. 681-701.

Nguyen, N. (2017), "The long run and short run impacts of foreign direct investment and export on economic growth of Vietnam", Asian Economic and Financial Review, Vol. 7 No. 5, pp. 519-527.

Rajan, R.G. and Subramanian, A. (2008), "Aid and growth: what does the cross-country evidence really show?", The Review of Economics and Statistics, Vol. 90 No. 4, pp. 643-665.

Sothan, S. (2018), "Foreign aid and economic growth: evidence from Cambodia", The Journal of International Trade and Economic Development, Vol. 27 No. 2, pp. 168-183.

Tripati Rao, D., Sethi, N., Dash, D.P. and Bhujabal, P. (2020), "Foreign aid, FDI and economic growth in South-East Asia and South Asia”, Global Business Review, pp. 1-17, doi: 10.1177/0972150919890957.

Ukhtiyani, K. and Indartono, S. (2020), "Impacts of Indonesian economic growth: remittances migrant workers and FDI", Journal of Economics and Policy, Vol. 13 No. 2, pp. 280-291, doi: 10.15294/ jejak.v13i2.23543.

Williams, K. (2018), "Are remittances good for economic growth? The role of political institutions", Applied Economics Letters, Vol. 25 No. 1, pp. 56-60.

$\mathrm{Xu}, \mathrm{B} .(2000)$, "Multinational enterprises, technology diffusion, and host country productivity growth", Journal of Development Economics, Vol. 62, pp. 477-493.

Yang, D. (2008), "International migration, remittances and household investment evidence from Philippine migrants' exchange rate shocks”, Economic Journal, Vol. 118 No. 528, pp. 591-630, doi: 10.1111/j.1468-0297.2008.02134.x.

\section{Appendix}

\section{List of countries}

Algeria, Argentina, Bangladesh, Bolivia, Botswana, Brazil, Burkina Faso, Cameron, China, Colombia, Costa Rica, Cote d'Ivoire, Egypt, El Salvador, Ghana, Guatemala, Guinea-Bissau, Honduras, India, 
Indonesia, Kenya, Madagascar, Malaysia, Mali, Mexico, Morocco, Mozambique, Namibia, Niger, Nigeria, Pakistan, Panama, Peru, Philippines, Senegal, Sudan, Thailand, Togo, Tunisia, Turkey and Venezuela.

\section{Low-income countries:}

Burkina Faso, Guinea-Bissau, Madagascar, Mali, Mozambique, Niger, Senegal and Togo.

Lower-middle-income countries:

Bangladesh, Bolivia, Cameron, Ivory Coast, Egypt, El Salvador, Ghana, Guatemala Honduras, India, Indonesia Kenya, Morocco, Nigeria, Pakistan, Philippines, Sudan and Tunisia.

\section{Lower-middle-income countries:}

Algeria, Argentina, Botswana, Brazil, China, Colombia, Costa Rica, Malaysia, Mexico, Namibia, Panama, Peru, Thailand, Turkey and Venezuela.

Source(s): Word Bank (2017)

\section{Corresponding author}

Amna Zardoub can be contacted at: zardoubamna@gmail.com
Effect of financial flows on economic growth

For instructions on how to order reprints of this article, please visit our website: www.emeraldgrouppublishing.com/licensing/reprints.htm Or contact us for further details: permissions@emeraldinsight.com 